\title{
The role of brokers in a workplace development programme targeting SMEs
}

Agneta Halvarsson Lundqvist and Maria Gustavsson

The self-archived postprint version of this journal article is available at Linköping University Institutional Repository (DiVA):

http:/ / urn.kb.se/ resolve?urn=urn:nbn:se:liu:diva- 151603

N.B.: When citing this work, cite the original publication.

Halvarsson Lundqvist, A., Gustavsson, M., (2018), The role of brokers in a workplace development programme targeting SMEs, European J ournal of Training and Development.

https:// doi.org/ 10.1108/EJTD-04-2018-0037

Original publication available at:

https:/ / doi.org/ 10.1108/ EJ TD-04-2018-0037

Copyright: Emerald

http:// www.emeraldinsight.com/ 


\title{
The role of brokers in a workplace development programme targeting SMEs
}

\author{
Abstract \\ Purpose: The purpose of this article is to investigate the development of a WPDP \\ targeting SMEs by focusing on the people who acted as brokers providing cross- \\ boundary connections between its collaborating partners.
}

Design/methodology/approach: The material, from interviews with 32 individuals and 11 meetings, was analysed in a boundary-crossing framework, which provided tools to reveal how the roles of brokers at different levels (operative, strategic, and national) of the WPDP affected its development.

Findings: The findings indicate that cross-boundary connections were made by persons who acted as brokers within and between different levels of the WPDP. The brokers who provided cross-boundary connections between different levels of the WPDP were found to play the most important role for the prompt development of the WPDP. Originality/value: Apart from unique empirical material depicting the development of a collaborative venture between national and regional stakeholders of the manufacturing industry, the value of this study is the attention given to the people behind the policymaking of publicly funded national WPDPs, revealing the complex business of developing policy-driven competence development activities to employees in SMEs.

Keywords: broker, cross-boundary connections, workplace development programme, SME, manufacturing industry, programme development 


\section{Introduction}

This article reports on the findings from a study conducted in a workplace development programme (WPDP) aiming to strengthen Swedish small and medium sized manufacturing enterprises' (SMEs) competitiveness in a global market by increasing the SMEs innovation and production capabilities. WPDPs are common types of collaborative ventures in Northern Europe and receive public funding to support the development of workplaces or change projects in organizations, and they are quite often used to operationalize European Union, national or regional policies (Brulin and Svensson, 2012). Networking, education or coaching of employees and managers is frequently included in the support that participating organizations receive from a WPDP (Alasoini, 2016). To date, more than 200 manufacturing enterprises (SMEs) throughout Sweden have participated in the WPDP. Ten organizations (elaborated in the research setting section) collaborated as partners of the WPDP to develop support in the form of university education and on-site coaching. It was necessary to develop the support for the enterprises quickly such that the SMEs could ideally increase their innovation and production capabilities before the programme ended.

However, a challenge faced by WPDPs is to create a partner collaboration that works and to both develop and provide support to organizations in a short time span (usually 2-3 years) (Brulin and Svensson, 2012). The rapid development of a WPDP requires a sufficient number of meetings in which individuals with the appropriate functional roles from the collaborating organizations attend (Halvarsson and Kock, 2015). Such types of collaborative meetings, which Wenger (2010) has termed boundary encounters, provide opportunities to connect knowledge across multiple practices to achieve or develop something new, in this case, a WPDP targeting SMEs. In that sense, developing a 
WPDP may be considered as developing a 'practice of crossing boundaries' that develops its own pattern of interaction and actions and a history of shared interest, tools and routines (Wenger, 2010). Such a practice contributes to creating not only bridges across boundaries (cross-boundary connections) but also knowledge of how the collaborating organizations address their own boundaries in relation to the other partners (Wenger, 2000). The notion of boundaries refers to 'edges' (Wenger, $2010 \mathrm{p}$. 131) that are constantly (re)negotiable yet shape clear distinctions between the inside and outside of a practice (such as an organization or part of an organization).

In this article, our interest is directed towards the people who act as brokers and who negotiate their participation at the boundaries by making compromises and legitimizing their brokering roles to provide the cross-boundary connections necessary to develop the WPDP. More precisely, the purpose of this article is to investigate the development of a WPDP targeting SMEs by focusing on the people who acted as brokers providing cross-boundary connections between its collaborating partners. Hence, the people that are focused on in this study are representatives from the collaborating organizations of the manufacturing industry who worked at the boundaries to find solutions for both quick and sustainable development of the WPDP, which ultimately benefited the SMEs that the WPDP supported. The research questions are as follows: 1) In what meetings and for what purpose did brokers meet to develop the WPDP? 2) What roles did the brokers play at different levels of the WPDP to provide cross-boundary connections between the collaborating partner organizations? Two types of sources developed the research questions: (1) interviews with persons representing the ten WPDP partner organizations and (2) notes from the WPDP meetings. 
The significance of the present study is its contribution to knowledge about 'brokers positioned at the intersection of different hierarchical levels' [of interorganizational partnerships], a topic that has received relatively sparse attention in the literature (Akkerman and Bruining, 2016, p. 280). Thus, the main contribution is to gain more empirical knowledge about the roles of the persons who are given or take on the position of brokers (active agents), providing cross-boundary connections to develop a large-scale interorganizational collaborative venture such as a WPDP partnership. From a practical point of view, it is important to consider the role of brokers in organizing policy-driven competence development activities to develop manufacturing SMEs.

In the following section, the concept of broker is elaborated using a theoretical boundary-crossing framework. The subsequent section provides an overview of the research settings and research methods. Next, the findings depict the brokers' encounters and their roles at the three levels of the WPDP. A discussion and conclusions end the paper.

\section{Theoretical framework}

In this article, the term broker refers to persons engaged in the development of the WPDP who work at the boundaries of their own organizations to create the necessary cross-boundary connections to develop the WPDP (Wenger, 2000). However, the concept of broker is multifaceted, as evidenced by the wide range of terms used to describe this position, including boundary spanner, bridge, co-ordinator, gatekeeper, gobetween, knowledge broker, liaison, and mediator (Long et al., 2013). Brokers can be given or take on central positions at cross-connecting boundaries between collaborating organizations, although who is or will become a broker is not always visible (Akkerman and Bruining, 2016). The roles of brokers may include taking care of a specific 
boundary, moving from one place to another or exploring new frontiers (Wenger, 2010). Brokers may combine elements from different contexts in which they engage professionally into something new (Engeström and Sannino, 2011), and they take advantage of personal relationships with other brokers to achieve their goals (Wenger, 2000). When brokers combine different elements in a joint large-scale venture, such as a WPDP, the brokers are forced to negotiate their competencies with other brokers' competencies because they may encounter problems that they have not come across before, and when they do so, they have to build cross-boundary connections between the organizations that they represent (Wenger, 2000). Boundaries are defined as sociocultural differences between the collaborating organizations that lead to discontinuities in the brokers' interactions and actions (Akkerman and Bakker, 2011). As stressed by Akkerman and Bakker (2011, p. 152), 'boundaries, as a meaningful analytic concept, are about sociocultural differences leading to discontinuities rather than about sociocultural diversity per se', even though many scholars use the term boundaries when discontinuities due to social differences are expected, not empirically shown. Such a conceptualization of boundaries may be problematic because it suggests that the only boundaries between collaborating organizations are sociocultural differences, which is not the case (Akkerman and Bakker, 2011). As an example, grounds for discontinuities in interaction that may or may not derive from sociocultural differences would be the inability to gather persons with suitable competence to make sense of and decide how to handle an emerging problem during broker encounters. A cause for discontinuities in action that may or may not derive from sociocultural differences may be the absence of persons with the authority to make the necessary changes to solve a problem during broker encounters (Halvarsson \& Kock, 2015). 
Relying on brokers to build cross-boundary connections between partners can be precarious, and this precariousness frequently stems from the individual broker's positions in the organization that he or she represents, which may be central or peripheral (Akkerman and Bruining 2016, Wenger 1998). Brokers' positions are often peripheral because they cannot fully engage in activities in their (home) organizations due to their work at the edges of their organization, which also indicates that they seldom have the leverage needed to make changes in their own organizations (Wenger 1998). Examples of boundary workers at their own organizations' edge would be consultants or coaches who spend more of their working time in the organizations they coach than they do in their own organization. Such persons are seldom strategic (central) decision makers in their own organizations. Wenger (2010) emphasises that because brokers such as those mentioned often do not fully belong to an organization, their value is easily unnoticed.

Moreover, brokering skills are developed over time, and realizing the importance of crossing boundaries to solve problems seems to be one such skill (Fortuin and Bush 2010); building trust among partners seems to be another (Morse, 2010). Overall, the characteristics of a broker can affect the maturity level of a coalition (Kilpatrick et al., 2009), which indicates that personal engagement is important for individuals who act as brokers for collaborating organizations. Brokers may even thrive as a result of working at the boundary where they can create new things (Wenger, 2010). However, some brokers want to achieve a balance between actors, whereas others want to control ongoing activities; thus, the brokers' roles may be political (Hong and O, 2009; Kimble, et al., 2010). 
When brokers collaborate across boundaries to build cross-boundary connections, they learn, and their learning can set organizational change in motion (Akkerman and Bruining, 2016; Engeström et al.,1995; Gustavsson and Säfsten, 2017; Wenger, 2000). Thus, the concept of boundary crossing has expanded from its original sense, in which it refers to a person's potential learning through movements and interactions across different places (Suchman, 1994), to learning that may transform organizations (Akkerman and Bakker, 2011; Akkerman and Bruining, 2016). In this article, when brokering or boundary crossing is approached, learning is defined as a social and participatory process embedded in the work (Lave and Wenger, 1991) of the persons who developed the WPDP. The organizations that may change because of brokers' learning are both the temporary organization of the WPDP and the collaborating organizations.

Through an extensive study of the boundary-crossing literature, Akkerman and Bakker (2011) investigated brokers' learning by categorizing boundary-crossing processes into four different types: identification, reflection, coordination and transformation. Referring to Hasu and Engeström (2000), Akkerman and Bakker (2011) demonstrate that processes of transformation, that is, action that results in something new, begin in the brokers recognizing of a shared problem space, often after having identified a deficiency or a problem, which puts pressure on the collaborating partners to change their current relation. Increasing global competition for SMEs is one such a problem. As the collaboration deepens, brokers may also engage in processes of coordination, which refers to actions that aim to routinize joint work processes (Akkerman and Bakker, 2011). Pointing to Star (2010), Akkerman and Bakker (2011) note that in processes of coordination, a dialogue may be established to maintain the flow of work towards one 
or more shared objects that do not require full consensus (see also Star, 2010; Star and Griesemer, 1989). Akkerman and Bakker (2011) sees coordination and transformation processes as opposite from each other. Coordination allows for smooth cooperation where any previous boundaries have been crossed; conversely, transformation seems to be processes that include confrontation in brokers working together to build something new 'by virtue of their differences' (Akkerman and Bakker 2011, p. 152). However, Akkerman and Bakker (2011) make it clear that brokers must engage in interaction in the form of identification and reflection before being able to transform or coordinate a large-scale partnership venture. Identification processes include identification of 'the other', i.e., (re)definition of how the various practices are different from each other, which may legitimate co-existence (Bogenrieder and van Baalen, 2007; Considine, 2006). Reflection includes taking 'the perspective of the other' and becoming aware of differences (Boland and Tenkasi, 1995; Williams et al., 2007). Referring to the four previously mentioned authors, Akkerman and Bakker (2011) conclude that the brokers taking of the 'perspective of the other' may result in the formation of an identity that informs the brokers of their future practice, similar to how an evaluation may inform them about future steps (Akkerman and Bakker, 2011). Thus, identification and reflection processes are ways for brokers to make sense of things, whereas coordination and transformation processes include some form of action (Akkerman and Bakker, 2011). The present article brings attention to the brokers' role in boundary-crossing processes that occur at different levels of the WPDP. Akkerman and Bakker's model is used as a lens to clarify that such processes may lead to the broker's making sense of things (identification and reflection) or to actions with more practical implications requiring changes (coordination or transformation) within the WPDP or the collaborating organizations. 
Regarding boundary crossing at different levels, Filip and colleagues (2016) noted the importance of identifying brokers at different levels of projects in a study of a regional programme encompassing collaborative innovation projects between researchers, small firms and independent third parties. They identified two types of brokers, one at a meta level (the regional programme level) and one at a micro level (hands-on facilitators). The work of the two identified types of brokers, i.e., brokers engaged in organizations that fund and organize regional programmes and brokers that are able to provide 'handson' support to projects within the programme, was, for natural reasons, different. Filip and colleagues (2016) touch on the notion that the brokers' positions enable them to combine elements from the different contexts in which they engage professionally to develop the regional programme.

To summarize, a few studies addressing multi-level collaborative ventures such as WPDP partnerships highlight that brokers have an important role in building crossboundary connections between collaborating organizations.

\section{Research setting}

The research was carried out in a WPDP aiming to strengthen Swedish manufacturing SMEs' competitiveness in the global market by increasing their innovation and production capabilities. Table 1 lists the collaborating organizations of the WPDP and the persons who became the most central brokers of the WPDP. These persons are regarded as brokers because they combined elements such as different types of competencies and monetary resources from their respective organizations and because they created cross-boundary connections between the partner organizations in their 
capacity as links or providers of relations. Hence, we refer to such persons as brokers.

Table 1. Collaborating organizations of the WPDP, brokers and their official roles in their respective organizations and in the WPDP.

\begin{tabular}{|c|c|c|}
\hline Collaborating organizations & $\begin{array}{l}\text { Brokers' official roles in the partner } \\
\text { organizations }\end{array}$ & Brokers' official roles in the WPDP \\
\hline $\begin{array}{l}\text { Funders: } \\
\text { Vinnova } \\
\text { Swedish Knowledge Foundation } \\
\text { Nutek }\end{array}$ & Coordinating officials & $\begin{array}{l}\text { Procurement of funds and on-going funder } \\
\text { evaluation of WPDP }\end{array}$ \\
\hline National Metal Workers' Union & Former General Secretary & Steering-board chairperson \\
\hline $\begin{array}{l}\text { The Association of Swedish } \\
\text { Engineering Industries }\end{array}$ & $\begin{array}{l}\text { Engaged in the association in his } \\
\text { capacity as a top manager in a member } \\
\text { organization }\end{array}$ & Vice steering-board chairperson \\
\hline \multirow{3}{*}{$\begin{array}{l}\text { Professional education school } \\
\text { within a technical university }\end{array}$} & CEO & Member of management group and future group \\
\hline & $\begin{array}{l}\text { Former employee engaged and } \\
\text { knowledgeable in Lean production }\end{array}$ & $\begin{array}{l}\text { Marketing and organizing Lean seminars for } \\
\text { SME's, member of management group }\end{array}$ \\
\hline & Teachers and researchers (2) & Lean coaches \\
\hline \multirow[t]{3}{*}{ Technical R\&D institute } & CEO & Member of management group and future group \\
\hline & Researcher and Lean coach & Programme director \\
\hline & Lean coaches and researchers (6) & Lean coach \\
\hline Partner University 1 & Teachers and researchers (2) & Lean coach \\
\hline Partner University 2 & Teachers and researchers (2) & Lean coach \\
\hline Partner University 3 & Teachers and researchers (2) & Lean coach \\
\hline
\end{tabular}

The initiation of the studied WPDP was a result of discussions between the three major funding organizations listed at the top of Table 1 and the two national labour market associations, which had a history of prior collaboration with the organizations that became the WPDP operators. A professional education school and a technical research and development (R\&D) institute operated the WPDP jointly and provided most of the coaches. Regional universities provided additional coaches. Brokers representing the technical R\&D institute and the professional education school shaped the WPDP plan in conjunction with brokers representing the two labour market associations and the three funding organizations. The plan pictured a WPDP that was to educate and provide onsite coaching to support SMEs to implement Lean production (Womack, 1990) to 
strengthen their production and innovation capabilities. The education consisted of preexisting university Lean courses. However, unique on-site coaching for SMEs needed to be developed before the coaching could begin because, according to the interviews, coaching methods that specifically target SMEs in the manufacturing industry are scarce. The SME's 'Lean coaching' method built on Lean principles such as continuous improvement, standardised processes, levelled production, visual inspection and Just-InTime practices (Womack et al. 1990), but a certain amount of flexibility was included so that the on-site coaching could be adapted to each SME's specific needs. By the end of the first programme period (3 years), 14 'Lean coaches' had managed to support managers and employees in 59 SMEs throughout Sweden, and a minimum of two persons in each SME had participated in the university Lean courses. Approximately 150 SMEs were supported during the second and third period.

\section{Method}

A qualitative case study design was used (Yin, 1984). The first author of the present article conducted interviews with 32 individuals and collected note from 11 meetings of the programme. In total, 45 interviews were conducted over a three-year period; the programme director was interviewed on three occasions and the chief executive officers (CEO) of the professional education school and technical research, chair and vice chairpersons of the steering board, three representatives of the funding organizations and some Lean coaches were interviewed twice, and other representatives from the partner organizations once. Table 2 presents an overview of the representatives, the types of data, focus at interviews and meetings, and the number of interviews or meetings, which were performed during the three-year period (Table 2).

Table 2. Data, focus at interviews and meetings, and numbers of interviews/meetings. 


\begin{tabular}{|c|c|c|}
\hline Type of data & Focus at interviews and meetings & Number \\
\hline Interviews & $\begin{array}{l}\text { Programme content, organization and on- } \\
\text { going processes (year 1) }\end{array}$ & 25 \\
\hline \multicolumn{3}{|l|}{$\begin{array}{l}\text { (selected coaches, educators, steering board members, } \\
\text { management group members, funders, union leaders, } \\
\text { and employer association representatives) }\end{array}$} \\
\hline (selected coaches and management group) & $\begin{array}{l}\text { Conditions for and interest for cooperation } \\
\text { among partners at the operative level (year } \\
\text { 2) }\end{array}$ & 8 \\
\hline $\begin{array}{l}\text { (management in partner universities, management } \\
\text { group, selected coaches, selected steering group } \\
\text { members) }\end{array}$ & $\begin{array}{l}\text { Organizing of programme activities and } \\
\text { reflections about future collaboration } \\
\text { including the partner universities (year 3) }\end{array}$ & 11 \\
\hline (programme director) & $\begin{array}{l}\text { Continued work in the programme and a } \\
\text { retrospective view of the initial cooperation } \\
\text { (follow-up interview) (year } 3 \text { ) }\end{array}$ & 1 \\
\hline \multirow[t]{3}{*}{ Meetings } & $\begin{array}{l}\text { Programme's organization and partners' } \\
\text { collaboration (seminars organized by } \\
\text { researchers during year } 1 \text { and } 3 \text { ) }\end{array}$ & 3 \\
\hline & $\begin{array}{l}\text { Various emerging issues concerning } \\
\text { programme activities (meetings organized by } \\
\text { programme management throughout the } \\
\text { programme period) }\end{array}$ & 5 \\
\hline & $\begin{array}{l}\text { Reports on progress in programme and } \\
\text { activities and discussions about future } \\
\text { cooperation between partners (meetings } \\
\text { organized by funders during year } 2 \text { and } 3 \text { ) }\end{array}$ & 2 \\
\hline
\end{tabular}

The number of interviews was not set at the start of the research project. The goal of the process was to allow the results from each set of interviews lead into the next, both in terms of who to interview and the themes for the interview. The procedure for selecting interviewees was the following: the first set of interviewees was selected in collaboration with the WPDP director. Important criteria in the selection of interviewees included that the interviewees had an official role in the WPDP and were perceived as a key person in the development of the WPDP by the programme director or, as the research project progressed, by other interviewees. This criterion became a means to identify who acted as a broker providing cross-boundary connections between the WPDP partners. A semi-structured interview protocol was used that included themes regarding the organizing of the WPDP and collaboration between partner organizations. Examples of interview questions were what is your role in the WPDP, in what constellations do you meet, what processes and activities are taking place during your 
collaboration to develop the WPDP and do you see any emerging risks in the development of the WPDP?

The transcribed interviews (45 in total, with 32 persons) were conducted on site (16) or by telephone (29) and lasted 50 minutes on average. Seven interviewees requested that their interviews not be voice-recorded, only simultaneously transcribed. Each transcript was sent to the interviewed person within a week asking him or her to comment, add or rephrase. The changes made, such as choice of words or word order, were minor.

The interviewees attended meetings that were arranged as cross-boundary encounters, and they did so in different constellations and at different levels of the WPDP (elaborated in the findings section). The first author of the present article observed or participated in meetings organized by either programme management or the funding organizations. The research role was an external one, although in one of the funding organizations' meetings, the first author of the paper presented findings from interviews but did not take part in the subsequent discussion. In addition, the research team arranged three meetings in which they reported findings from the interviews. In these meetings, the first author of the paper led the discussion among the participants by asking questions to try to clarify the findings or gain more knowledge about the development of the WPDP. The notes (3-10 A-4 documents per meeting) capture the discussions in the meetings. The documentation includes both summaries and verbatim, which allowed the researchers to capture discussions between representatives of the partner organizations and to note what was said by whom. 
Data analysis based on the interview transcripts was performed throughout the research project to follow the development of the WPDP. The content of the interviews was analysed to obtain a thick description (Geertz, 2000) of the organization and development of the WPDP, including who was involved and where they met. During this analysis, two major patterns in the development of the WPDP with consequences for its contribution to SMEs emerged (development of the coaching method and development of a more permanent organization founded on the WPDP).

After the research project ended, a re-analysis was conducted. In this second phase, a qualitative content analysis (Bryman, 2004) based on the interview transcripts and notes from meetings were made. The researchers could only study in full those formal group meetings that they had access to or that were described to them in detail by the interviewees, which is why some of the formal group meetings were not studied (Table $3)$.

Concepts such as brokers, brokering skills and cross-boundary connections presented in the theoretical framework were used to identify the levels of the WPDP broker's encounters (meetings) and the roles brokers played in creating cross-boundary connections between the collaborating organizations during these encounters. To achieve a deeper analysis and distinguish between broker roles at different WPDP levels, Akkerman and Bakker's (2011) analysis model depicting the four types of boundary-crossing processes was used to separate interactions, i.e., interactions between the two groups of brokers making sense of the development of the WPDP (identification or reflection) from actions that ensured actual changes during the development (coordination or transformation). In the analysis, the characteristics of 
brokers became visible at the operative and strategic levels of the WPDP, and accordingly, they are presented in the findings.

Ethical committee approval is not obligatory by Swedish law for studies such as the presented work. Nevertheless, procedures according to Swedish law of ethical considerations in research such as informed consent were followed.

\section{Findings}

The following section presents the brokers meetings to develop the WPDP and the roles the brokers played at different levels in the WPDP to provide cross-boundary connections between the collaborating organizations.

\section{Brokers' encounters}

There were multiple, organized meetings of groups with specific aims, reflected in the group titles, although it is to be assumed that brokering occurred in more informal settings too (Wenger, 1998). Table 3 provides an overview of all the formal groups at the multiple WPDP levels in which brokers met.

Table 3. Major formal groups in which brokers met (elaborated groups in italics).

\begin{tabular}{|c|c|c|c|}
\hline Levels & Operative & Strategic & National \\
\hline $\begin{array}{l}\text { Groups } \\
\text { and } \\
\text { brokers }\end{array}$ & $\begin{array}{l}\text { Coaching group } \\
\text { People acting as brokers for: } \\
\text { Technical R\&D institute } \\
\text { Professional education school } \\
\text { (only coaches) } \\
\text { Partner universities } \\
\text { Management group } \\
\text { People acting as brokers for: } \\
\text { Technical R\&D institute } \\
\text { Professional education school } \\
\text { Reflection day group } \\
\text { People acting as brokers for: } \\
\text { Technical R\&D institute } \\
\text { Professional education school } \\
\text { Partner universities } \\
\text { Lean consultancy firms (not } \\
\text { official partners) }\end{array}$ & $\begin{array}{l}\text { Steering board } \\
\text { People acting as brokers for: } \\
\text { National Metal Workers' Union } \\
\text { Employers' Association } \\
\text { (4 enterprises and } 1 \text { university } \\
\text { - not official partners) } \\
\text { Future group } \\
\text { People acting as brokers for: } \\
\text { Technical R\&D institute } \\
\text { Professional education school } \\
\text { National Metal Workers' Union } \\
\text { Employer Association }\end{array}$ & $\begin{array}{l}\text { WPDP group } \\
\text { People acting as brokers for: } \\
\text { National Metal Workers' Union } \\
\text { Employer Association } \\
\text { Funders (3) } \\
\text { Professional education school } \\
\text { Technical R\&D institute } \\
\text { (eventually also regional } \\
\text { universities (3)) } \\
\text { Funders' group meetings } \\
\text { People acting as brokers for: } \\
\text { Funders (3) }\end{array}$ \\
\hline
\end{tabular}


In the following, the focus is on the roles of brokers in the italicized groups listed in

Table 3, which are the coaching group, the steering board, the future group and the WPDP group.

Many of the persons that acted as brokers had collaborated before, in various constellations and at different times, to develop projects or programmes that supported manufacturing enterprises. A steering-board member said the following:

The prior connections in [name of programme] and [name of programme] were important in driving this WPDP (steering-board member).

By the same token, the CEO of the technical R\&D institute contemplates the importance of individual brokers' prior relationships in other cross-boundary practices as follows:

This is always about the individuals. You may talk about us [the research institute] and them [a regional university] as 'big lumps', but it is always about who wants to work with whom. If you find each other and get to know each other [as individuals], there will always be following projects, and you enjoy the cooperation. I think that people always underestimate the importance of the individual. (CEO Technical R\&D Institute).

When asked in what fora learning occurred in the WPDP, the WPDP communicator explained that the partners jointly developed the WPDP in meetings, such as the one he relates below:

One example is the reflection days when everyone [that operates the WPDP] gather. It is amazing, the amount of knowledgeable people that meet. [...] We adjust everything along the way, and we keep refining our operation and that becomes an inspiration for similar WPDPs (WPDP communicator). 
The excerpts above indicate that brokers crossed boundaries to be and create crossboundary connections between WPDP partners. The meetings were a type of encounter for brokers in which they shared competencies and made cross-boundary connections (Wenger, 2010). As Table 3 illustrates, the meetings took place at three WPDP levels and are elaborated next. The next section shows the brokers' role, including their characteristics, in providing cross-boundary connections between the collaborating partner organizations.

\section{Brokers' roles at the operative WPDP level}

At the operative level, organized meetings to develop different activities offered to the SMEs occurred in multiple groups (Table 3). In the coaching group, coaches representing the technical $R \& D$ institute, the professional education school and each of the three partner universities met and created cross-boundary connections necessary to develop the coaching methods. On-site coaching was the main support that the participating SMEs received from the WPDP. According to the programme director, the coaching method was something that had to be developed:

\footnotetext{
There is certainly a lot of learning in the coaching group [irony] [...] Their task was not clear from the start $[\ldots]$ and the development of the coaching method had to be done quickly $[\ldots]$ it has been completed thanks to competent persons. (Programme director)
}

Partner universities, the technical R\&D institute and the professional education school employed the company coaches engaged by the WPDP, and most of them were experienced Lean coaches, as indicated in the following excerpt:

These people are certainly no novices. They are experienced [...]. They have a rock-solid past in this area. (Lean coach 2) 
Because of their expertise, which they had obtained in their respective organizations (and possibly elsewhere previously), the company coaches were able to contribute different elements of coaching. Such elements included which SME staff to coach and what Lean tools to include. The brokers also debated the degree to which coaching activities should be adjusted to meet the local contexts of the SMEs. The work of the coaching group is portrayed in the following excerpt, which also depicts highly motivated coaches who ultimately reached consensus about the coaching methods.

The working climate in the coaching group and the will to develop the coaching material relatively fast have been excellent. When the coaches are out there [in the SMEs] they all stand up for their joint coaching methods. A consensus has developed. We have discussed what is best, but we have sorted out our different opinions and then we have confirmed the coaching material. We have different competencies, different backgrounds and different experiences (Lean coach 3).

\section{Essential cross-boundary connections to develop the coaching method}

The coaches in the coaching group were able to solve most emerging problems among themselves during these meetings, which indicates both that they were able to create cross-boundary connections to make sense of the situation and that they had sufficient leeway to take action to remedy the situation. However, a problem related to copyrights for the material that was to be used emerged among company coaches. Some coaches could not gain permission to use models and other resources originating from the organizations they represented, which slowed down the development of coaching methods. The following quote depicts both problems:

In the coaching group, which has worked on coaching methods, there was a problem with copyright. We had to develop a lot from scratch. We worked intensively from the start, yet 
when we started coaching the enterprises this became increasingly difficult (Lean coach and education administrator).

The coaches and programme management highlighted the problem with obtaining copyright from the WPDP partners on material that the coaches aimed to use as part of the WPDP coaching method to members of the steering board. Some members of the steering board analysed the material rights problem together with the coaching group, and the steering board's chair and vice chairpersons were later able to step in and solve the problem by putting pressure on some of the collaborating organizations to refrain from claiming copyright on part of the training material. This process indicates that the coaches, although highly experienced and able to make sense of the situation, were not central decision makers in their (home) organizations and consequently unable to move into a mode of action. Why the steering-board members were able to help solve the problem is touched upon in the next section.

\section{Brokers' roles at the strategic WPDP level}

At the strategic level of the WPDP, brokers created cross-boundary connections through a 'steering board'. Some of its members provided support and guidance to the operative management, reported to and discussed with brokers at the national level, and, as observed in the example depicting the coaching group, negotiated between partners to solve emerging problems in the development of the WPDP. The steering board's chairperson and vice chairperson became the two main brokers in the steering board. They were highly esteemed and had experience from prior collaboration between the two labour market associations and the other collaborating organizations, which may explain why they were able to put pressure on the collaborating organizations to void copyrights. The programme director said: 
You know, they all see the chairperson as someone on the same level as the general directors or CEOs because of his background. (Programme director)

The vice chairperson of the steering board expressed another reason for the steering board's ability to negotiate between partners:

The WPDP steering board is probably a little bit more than a traditional steering board. We don't just receive reports and documents as basis for our decisions, but we are out there, in the enterprises and we are active. We are out there to learn more [... The steering group needs to be trustworthy and give inspiration. Then, you have to use everyone's competencies although we have different backgrounds (vice chairperson of steering board).

One of the funder coordinators expressed that the funders indeed had given the steering board a strong mandate.

We [the funding organizations] have tried to give the strongest possible mandate to the steering board, maybe not formally but in practice. If you don't do that you can't find good people (coordinating official, funding organization).

In addition, another group, the future group, was formed at the strategic level.

Essential cross-boundary connections to develop the WPDP into a more permanent organization

The future group members included CEOs from the technical R\&D institute and the professional education school, the steering-board chairperson, the vice chairperson and the programme director. The group was expected to make suggestions regarding how to continue support to SMEs after the initial WPDP. The following excerpts describe the aim of the future group and the somewhat unclear roles of the brokers in it: 
The future group discusses with the programme management group, to define were we should be after this WPDP, what we will do in the future (vice chairperson of steering board).

Ideally, we connect the steps of development and it is the strategic leaders that need to stay one-step ahead [...]. The future group needs to work with this now [said six months into the 3-year WPDP] (CEO of professional education school).

All of these people in the future group are very reasonable. You can discuss, constructively, about the things that are ... [a short moment of silence] but when you look at their roles, it becomes very fuzzy what lies in those roles (Programme director).

The excerpt above indicates that the roles of the brokers in the future group was not set but rather something they developed over time out of their own personal engagement in the WPDP, their prior knowledge and brokering skills. Furthermore, unlike the steering board and some of the groups on the operative and national levels, this group was not mentioned in the WPDP plan but rather had evolved out of the need to discuss future financing. The future group eventually became an important discussion partner at the national level in partner meetings, as depicted in the next section. Thus, the brokers who developed this group tried to make sense of how to continue contributing to SMEs' competitiveness. However, as shown in the next section, they needed resources that could only be negotiated by brokers at the national level to take action in the desired direction.

\section{Brokers' roles at the national WPDP level}

The constellation of brokers at the national level was engaged in developing Swedish SMEs' competitiveness in a global market. Thus, the funders organized partner 
meetings, which became cross-boundary connections at the national level. The director generals and CEOs of the five partners that had initiated the programme met in the meetings, which included coordinating officials from the funders, representatives from the labour market organizations and executives from the professional education school and technical R\&D institute. The original aim of these meetings was to share updates on progress and challenges in the programme and to discuss any issues that needed toplevel decision-making within the partners' organizations. However, initially, the top executives of partnering regional universities, which provided some of the Lean coaches, had not been invited to these encounters. The partner universities had not been engaged by the initiative takers to contribute to writing the programme plan and thus had not been involved with this group from the start. No reason was given for this in the interviews.

\section{Essential cross-boundary connections at the national level to continue strengthening}

\section{SMEs' competitiveness}

The following exemplifies how discussions in the funders' group (Table 3) and discussions in the future group converged at a meeting on the national WPDP level, when the first funding period was close to ending; this was the first partner meeting at which top-level executives from the partner university representatives, other than those employed as coaches, were present. In this meeting, members from the funder's group that organized the meeting created four randomly arranged groups and asked the participants to discuss the future possibility of making the temporary WPDP into a more permanent organization within the groups. After the group discussion, each group conveyed its conclusions through its appointed note taker. From the start, there had been a debate about how to sustain the education and coaching offered by the WPDP after the 
initial funding period such that more SMEs could join the programme. The future group members realized that this would only be possible through renewed funding from the funding authorities and support from the labour market parties at the national level. All partners' top management were invited to the meeting, and it had become clear to all that the funders would not fund a second programme period unless the WPDP met some new demands, which they clarified at the meeting. The funders required additional partner universities and more regional influence on the programme. They also demanded increased engagement from the top management of the universities' that were already partners. There had been complaints of low engagement from partnering regional universities among brokers from the technical R\&D institute and the professional education school, and brokers from the partner universities had complained about not being 'let in' fully in regards to governing or managing the WPDP. The following excerpt illustrates this:

The WPDP has in many ways become a way for the R\&D institute and [name of professional school] to develop their own organizations. Material that is distributed have their logos on them but not always the WPDP logo. (Person representing partner university)

During the meeting, the funders' demands and the possible demand operationalization was discussed along with the alleged lack of interest from partner universities and the alleged reluctance of other partners to include them. The following excerpt provides a glimpse of the table discussions among brokers from the different partner organizations. The person taking notes for group four stated the following:

The fourth table talked about the need for networking on three levels, for the coaches, for the educators and for the whole programme. This responsibility can no longer lie with the coaches (note taker, group 4). 
The quote reveals that this group discussed the need for encounters and brokers with sufficient authority to negotiate the release of the elements needed to develop a more permanent organization founded on the WPDP. The table discussions and subsequent discussions at the meeting resulted in an invitation to the partner universities to coauthor a new WPDP plan with the other partners, which they accepted. This agreement resulted in an immediate initial plan for their first programme plan meeting. The events that occurred in this encounter ultimately secured funding for the WPDP for three more years and thus secured more long-term cross-boundary connections between the collaborating organizations. Table 4 summarizes the findings.

Table 4. Different WPDP levels, brokers' roles and necessary cross-boundary connections.

\begin{tabular}{|c|c|c|c|}
\hline Levels & $\begin{array}{l}\text { Operative } \\
\text { (Coaching group) }\end{array}$ & $\begin{array}{l}\text { Strategic } \\
\text { (Future group) }\end{array}$ & $\begin{array}{l}\text { National } \\
\text { (part of WPDP group) }\end{array}$ \\
\hline $\begin{array}{l}\text { Primary aim at } \\
\text { the level }\end{array}$ & $\begin{array}{l}\text { Develop educational activities } \\
\text { and support SME's }\end{array}$ & $\begin{array}{l}\text { Develop their (home) } \\
\text { organizations and build a } \\
\text { more permanent organization } \\
\text { out of the WPDP }\end{array}$ & $\begin{array}{l}\text { Strengthen SME's } \\
\text { competitiveness }\end{array}$ \\
\hline $\begin{array}{l}\text { The brokers' } \\
\text { roles }(\mathrm{R}) \text { and } \\
\text { their character } \\
\text { (C) }\end{array}$ & $\begin{array}{l}\text { R: Develop unique coaching } \\
\text { method } \\
\text { C: } \\
\text { Highly experienced } \\
\text { Motivated }\end{array}$ & $\begin{array}{l}\text { R: Develop programme into } \\
\text { more permanent organization } \\
\text { C: } \\
\text { Central decision makers of } \\
\text { partner organizations or close } \\
\text { connection to such persons. } \\
\text { Highly esteemed } \\
\text { Brokering skills } \\
\text { Strong mandate } \\
\text { Active in visiting SMEs } \\
\text { Passion for developing the } \\
\text { manufacturing industry }\end{array}$ & $\begin{array}{l}\text { R: Develop (strengthen) } \\
\text { SMEs' competitiveness in a } \\
\text { global market by increasing } \\
\text { the SMEs innovation and } \\
\text { production capabilities } \\
\text { C: } \\
\text { Central decision makers of } \\
\text { partner organizations with } \\
\text { monetary resources or } \\
\text { influence in the } \\
\text { manufacturing industry }\end{array}$ \\
\hline $\begin{array}{l}\text { Central } \\
\text { brokers }\end{array}$ & $\begin{array}{l}\text { Coaches from partnering } \\
\text { organizations and programme } \\
\text { director }\end{array}$ & $\begin{array}{l}\text { CEOs of technical R\&D } \\
\text { institute and Professional } \\
\text { education school, the chair of } \\
\text { the steering board } \\
\text { (representing the union), the } \\
\text { vice chair (representing an } \\
\text { employer organization) and } \\
\text { programme director } \\
\text { (+ eventually officials from } \\
\text { partner universities) }\end{array}$ & $\begin{array}{l}\text { Directors general and CEO of } \\
\text { funding organizations (3), } \\
\text { management group of } \\
\text { national union, management } \\
\text { group of employer } \\
\text { organization }\end{array}$ \\
\hline $\begin{array}{l}\text { Necessary } \\
\text { cross- } \\
\text { boundary } \\
\text { connections } \\
\text { to make sense }\end{array}$ & $\begin{array}{l}\text { Between brokers at operative } \\
\text { level }\end{array}$ & $\begin{array}{l}\text { Between brokers at the } \\
\text { strategic level }\end{array}$ & $\begin{array}{l}\text { Between brokers at strategic } \\
\text { and national levels }\end{array}$ \\
\hline
\end{tabular}




\begin{tabular}{llll}
\hline $\begin{array}{l}\text { of the } \\
\text { situation }\end{array}$ & & & \\
\hline $\begin{array}{l}\text { Necessary } \\
\text { cross- } \\
\text { boundary } \\
\text { connections } \\
\text { to move from } \\
\text { making sense } \\
\text { into action }\end{array}$ & $\begin{array}{l}\text { Mainly: between coaches } \\
\text { employed by partner }\end{array}$ & $\begin{array}{l}\text { Mainly: between brokers at } \\
\text { the strategic and national } \\
\text { levels }\end{array}$ & $\begin{array}{l}\text { Between brokers at the } \\
\text { national levels }\end{array}$ \\
& $\begin{array}{l}\text { On occasion: between } \\
\text { members of future group } \\
\text { (including partner universities) } \\
\text { and coaches - i.e. brokers at } \\
\text { operative and strategic levels }\end{array}$ & \\
\hline
\end{tabular}

The roles brokers played at different levels in the WPDP to provide cross-boundary connections between the collaborating organizations are discussed in the next section.

\section{Discussion}

This study has provided insight into the development of a WPDP targeting SMEs by focusing on the people who acted as brokers providing cross-boundary connections between its collaborating partners. The findings revealed that persons who acted as brokers both served as and created the cross-boundary connections necessary to develop the coaching methods and secure the future financing to build a more permanent organization founded on the WPDP (c.f. Gustavsson and Säfsten, 2017; Long et al., 2013; Wenger, 1998). These persons acted as brokers at multiple WPDP levels (Filip et $a l ., 2016)$ with different primary agendas at each levels (operative, strategic and national).

At the operative level, persons in the management group and coaches acted as brokers aiming to develop the competence development activities that were part of the hands-on support to SMEs. The coaches were tasked with the development of a unique coaching method that would enable them to coordinate (Star and Griesemer, 1989; Star, 2010) the on-site coaching, and they started to make cross-boundary connections to support this aim. According to the findings, one of the most important characteristics of a broker at 
the operative level, other than wanting to work at 'the edge' to develop something new (Fortuin and Bush, 2010; Wenger, 2010), was expertise in their line of work. Brokers' expertise or deep knowledge ensured that the appropriate, already-tested elements (Engeström and Sannino, 2011) from the collaborating organizations were combined to create the new, unique coaching method of the WPDP targeting SMEs and that it was done promptly. This accomplishment indicates that the brokers had sufficient expert knowledge to make sense of the development of the coaching method and, on most occasions, sufficient leeway to act to develop the method accordingly. Such development at the operative level, for obvious reasons, would not have been possible without other brokers' interaction and action at the national level, which allocated funding.

The brokers at the national level aimed to strengthen Swedish SMEs' competitiveness in the global market at a larger scale, and to do so they needed to create the necessary cross-boundary connections to combine the monetary resources (elements) that were indispensable to operate the WPDP. The brokers coupled the elements with certain demands, aims and objectives, which they negotiated, making the roles of brokers at the national level political (Hong and O, 2009; Kimble et al., 2010). The brokers at the national level had to be central head figures with a mandate to make decisions in their own organizations if they were to ensure funds and allocate resources for the WPDP, which, according to Wenger (1998), usually meant that they could not spend too much time working at the edges of their own organizations.

At the strategic level, the brokers' agenda was to develop the WPDP but, seemingly, also their (home) organization. Persons on the steering board and within the future 
group who acted as brokers appeared to take it upon themselves to detect the boundaries between the partners and create the necessary cross-boundary connections as problems or opportunities emerged (Wenger, 2000). These persons were undoubtedly key for the prompt development of the coaching methods when they solved the copyright problem that had slowed down this important transformation process (Akkerman and Bakker, 2011). Several brokers at the strategic level had characteristics that, according to the literature (Fortuin and Bush, 2010; Morse, 2010; Wenger, 2010), would make them highly skilled brokers. The findings suggest that brokers at the strategic level were the ones that utilized their personal relationships the most (Wenger, 2000) and they aimed to build trust among the partners at the operative level, which presumably was important in the negotiations concerning the copyright problem that had slowed down the development of the coaching method (Morse, 2010). More precisely, the combination of brokering skills (Fortuin and Bush, 2010; Morse, 2010), engagement and, perhaps most importantly, a central position in a WPDP partner organization or a connection to brokers with such a position through a personal relationship (Wenger, 1998; 2010) enabled the transition from making sense (identification and reflection) to action (transformation) at the operative level. Thus, the coaching method was developed promptly.

Furthermore, the necessary cross-boundary connections to make sense of the on-going development of the WPDP at the strategic level preceded the negotiations about future funding at the national level, apparently making the negotiations smoother and quicker (Akkerman and Bakker, 2016). Identification of the willingness of partner universities to engage in the WPDP may have occurred at the strategic level, which would have contributed to legitimatizing the partner universities' co-existence (Bogenrieder and van 
Baalen, 2007; Huemer et al., 2004). Altogether, this indicates that the role of brokers at the strategic level was especially important for making cross-boundary connections between the partnering organizations to ensure both prompt development of a 'Lean coaching' method adapted to SMEs and adequate sustained support to SMEs on a larger scale to further strengthen SMEs' competitiveness. The movement from making sense of things to action (in the form of transformation) was possible because of the roles given to and taken on by the brokers at the strategic level (Akkerman and Bruining, 2016). Thus, the findings point towards a high maturity level of the complex crossboundary practice due to the characteristics of the brokers (Kilpatrick et al., 2009) because changes that were important in the development of the WPDP came about. However, the findings also reveal that a strong mandate to make necessary changes within the first programme period was included in the broker roles assigned.

\section{Conclusion and practical implication}

Developing a WPDP is a complex business of balancing leeway and monetary resources for those who develop competence development activities (here, to support SMEs) and engaging brokers who can take on the role of building cross-boundary connections between the WPDP partners when actions in the partner organizations are necessary to develop the support activities. The first conclusion is that the role of brokers, including their characteristics, is especially important for providing cross-boundary connections between the collaborating partner organizations at a specific level. However, building cross-boundary connections between the different levels of the collaborative venture was important to scale up the joint venture and make further use of the newly developed competence development activities. Thus, the broker's role within a level in the WPDP constituted a necessary but not exclusive condition that enabled action in line with the 
aim of national policy makers. Therefore, a practical implication for a collaborative venture, in the form of a WPDP, is to engage persons who are willing and adequately equipped to take on broker roles to build cross-boundary connections both within and between the WPDP levels. The necessary characteristics for such brokers differ according to their role and the WPDP levels in which they act. Cross-boundary connections both within and between the WPDP levels are important so that when brokers make sense of 'things' in critical operational phases but do not have the mandate to act upon their new knowledge, these things may be promptly acted upon at the next level. This also indicates that policy makers may want to be sure that the persons they ask to assume specific broker roles are willing to commit to their long-term aim, such as the aim to strengthen SMEs' competitiveness.

\section{References}

Akkerman, S. and Bakker, A. (2011), "Boundary crossing and boundary objects", Review of Educational Research, Vol. 81 No. 2, pp. 132-169.

Akkerman, S. and Bruining, T. (2016), "Multilevel boundary crossing in a professional development school partnership", Journal of the Learning Sciences, Vol. 25 No. 2, pp. 240-284.

Alasoini, T. (2016), Workplace Development Programmes as Institutional Entrepreneurs: Why they Produce Change and why they do not. (PhD thesis), Department of Industrial Engineering and Management, Aalto University. 
Brulin, G. and Svensson, L. (2012), Managing Sustainable Development Programmes: A Learning Approach to Change, Gower Farnham, Surrey.

Bryman, A. (2004). Social research methods (2nd edition), University Press, Oxford.

Bogenrieder, I. and van Baalen, P. (2007), "Contested practice: Multiple inclusion in double-knit organizations", Journal of Organizational Change Management, Vol. 20 No. 4, pp. 579-595.

Boland Jr, R. and Tenkasi, R. (1995), "Perspective making and perspective taking in communities of knowing”, Organization Science, Vol 6, No. 4, pp. 350-372.

Considine, M. (2006), "Theorizing the university as a cultural system: Distinctions, identities, emergencies", Educational Theory, Vol. 56 No. 3, pp. 255-270.

Engeström, Y., Engeström, R. and Kärkkäinen, M. (1995), "Polycontextuality and boundary crossing in expert cognition: Learning and problem solving in complex work activities", Learning and Instruction, Vol. 5 No. 4, 319-336.

Engeström, Y. and Sannino. A. (2011), "Discursive manifestations of contradictions in organizational change efforts", Journal of Organizational Change Management, Vol. 21 No. 3, pp. 368-387. 
Filip, D., Hansen, B. and Frølunde, T. (2016), "Interaction enablers, drivers and barriers of collaborative innovation projects between small firms and academia”, Danish Journal of Management \& Business, Vol. 80 No 1, pp. 25-42.

Fortuin, I. and Bush, S. (2010), "Educating students to cross boundaries between disciplines and cultures and between theory and practice", International Journal of Sustainability in Higher Education, Vol. 11 No. 1, pp. 19-35.

Geertz, C. (1973/2000), “The Interpretation of Cultures”, Basic Books, New York, NY.

Gustavsson, M. and Säfsten, K. (2017), “The learning potential of boundary crossing in the context of product introduction", Vocations and Learning, Vol.10 No. 2, 235-252.

Halvarsson Lundkvist, A. and Kock, H. (2015), "Program steering by learning”, in Elg, M., Ellström, P. E., Klofsten, M. \& Tillmar, M. (Eds.), Sustainable Development in Organizations: Studies on Innovative Practices, Edward Elgar Publishing, Camberley Surrey, UK, pp 77-92.

Hasu, M. and Engeström, Y. (2000), "Measurement in action: An activity-theoretical perspective on producer-user interaction”, International Journal of Human-Computer Studies, Vol. 53, pp. 61-89.

Hong, J. and O, F. (2009), “Conflicting identities and power between communities of practice: The case of IT outsourcing”, Management Learning, Vol. 40 No. 3, pp. 311326. 
Kilpatrick, S., Cheers, B., Gilles, M. and Taylor, J. (2009), "Boundary crossers, communities, and health: Exploring the role of rural health professionals", Health \& place, Vol. 15 No. 1, pp. 284-290.

Kimble, C., Grenier, C. and Goglio-Primard, C. (2010), "Innovation and knowledge sharing across professional boundaries: Political interplay between boundary objects and brokers", International Journal of Information Management, Vol. 30 No. 5, pp. 437-444.

Lave, J. and Wenger, E. (1991), Situated Learning: Legitimate Peripheral Participation, Cambridge University Press, Cambridge, UK.

Long, J., Cunningham, F. and Braithwaite, J. (2013), "Bridges, brokers and boundary spanners in collaborative networks: A systematic review", BMC health services research, Vol. 13 No. 1, pp. 158.

Morse, R. S. (2010), "Bill Gibson and the art of leading across boundaries", Public Administration Review, Vol. 70 No. 3, pp. 434-442.

Star, S. L. (2010), "This is not a boundary object: Reflections on the origin of a concept", Science Technology Human Values, Vol. 35 No. 5, pp. 601-617. 
Star, S. and Griesemer, J. (1989), “Institutional ecology, 'translations', and boundary objects: Amateurs and professionals on Berkeley's museum of vertebrate zoology”, Social Studies of Science, Vol. 19 No. 3, pp. 387-420.

Wenger, E. (1998), Communities of Practice: Learning, Meaning and Identity, Cambridge University Press, Cambridge, UK.

Wenger, E. (2000), "Communities of practice and social learning systems", Organization, Vol. 7 No. 2, pp. 225-246.

Wenger, E. (2010), "Conceptual Tools for CoPs as social learning systems: Boundaries, identity, trajectories and participation”, in Blackmore, C. (Ed.), Social Learning Systems and Communities of Practice, Springer.

Williams, J., Corbin, B. and McNamara, O. (2007), "Finding inquiry in discourses of audit and reform in primary schools", International Journal of Educational Research, Vol. 46 No. 1, pp. 57-67.

Womack, J., Jones, D. and Roos, D. (1990), The Machine that Changed the World: The Story of Lean Production: How Japan's Secret Weapon in the Global Auto Wars will Revolutionize Western Industry, Rawson Associates, New York.

Yin, R. K. (1984), Case Study Research: Design and Methods, Sage Beverly Hills, CA. 